\section{Congress debates stem cell research}

A US Senate subcommittee has held hearings to discuss legislation that would allow federally funded scientists to derive human embryonic stem cell lines. Bill S.2015.IS, proposed by Senators Arlen Specter (R-PA) and Tom Harkin (DIA), was presented to the appropriations subcommittee on labor, health and human services, education and related agencies, which heard testimony from those for and against the proposal. The bill will be voted on this month.

Allen Spiegel, director of the National Institute of Diabetes and Digestive and Kidney Diseases, and Gerald Fischbach, director of the National Institutes of Neurological Disorders and Stroke (NINDS), explained the scientific and medical potential of human pluripotent stem cell research to the subcommittee. Actor Christopher Reeve appealed to lawmakers, urging them to support the bill, asking "Is it more ethical for a woman to donate unused embryos, or let them be tossed away as garbage when they could save thousands of lives?"

Meanwhile, Senator Sam Brownback (R-KA) compared stem cell research to tent stem cells.
Nazi experiments on people in World War II. And Mary Jan Owen, executive director the National Catholic Office for Persons with Disabilities, insisted that stem cells derived from adults are a suitable alternative to embryonic pluripo-

Fischbach disagreed with Owen's viewpoint, stating "Pluripotent and adult stem cells are not qualitatively alike. Pluripotent stem cells have truly amazing abilities to self-renew and to form many different cell types ... in contrast the full potential of adult stem cells is uncertain, and, in fact, there is

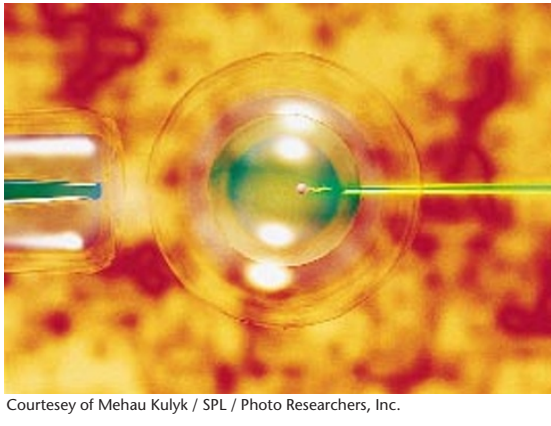

or not government-funded scientists should be allowed to use taxpayer money to derive their own stem cells from discarded embryos, the scientists themselves are still waiting for the release of federal guidelines outlining what kinds of experiments they can do with cells already derived. Although the public comment period on the draft version of the guidelines ended 22 February, the NIH shows no signs of publishing the final version, claiming that the delay is necessary because they are proceeding with the utmost caution into this area of research, given the problems that have occurred with NIHfunded gene therapy research.

evidence to suggest they may be more limited". Fischbach added that unlike pluripotent stem cells, adult stem cells may be only capable of dividing a limited number of times, which would limit their therapeutic usefulness.

While politicians battle over whether

\title{
Researcher stockpiled salmonella and explosives
}

Federal and state law enforcement officials in southern California continue to investigate the strange case of a biomedical researcher who stored cholera and typhoid fever organisms at his home along with automatic weapons and explosives. Authorities are also looking into the researcher's past links to South Africa's military biological weapons program.

The physician-scientist in question, Larry C. Ford, committed suicide in March after a murder-for-hire plot he hatched against his business partner, James Patrick Riley, went awry. Riley survived after being shot in the cheek when arriving at Biofem, an Irvinebased biotechnology company that Riley and Ford co-founded. The two claimed to be developing a new type of female contraceptive and were reportedly testing it on prostitutes in South Africa. Irvine police have charged Dino D'Saachs, a long-time friend of Ford's, with the attempted murder of Riley. "It was a financially based motive and we're trying to find out whether there was a conspiracy or a plan to shoot him (Riley)," says lieutenant Sam Allevato.

In addition to a cache of illegal weapons and explosives in Ford's backyard, police found glass vials containing organisms that were later determined to be cholera and typhoid fever organisms. More than 200 residents of Ford's Irvine neighborhood were evacuated for three days during the search. On 1 May, however, local health officials announced that testing by the Centers for Disease Control and Prevention in Atlanta had determined the organisms were not dangerous and that the local people were not at risk, says Hildy Meyers, director of communicable disease control for the Orange County Department of Health.

The Federal Bureau of Investigation would not comment on their investigation into what Ford was doing with the organisms. However, in the early 1990 s he served as an unofficial, unpaid advisor to "Project Coast," a biological weapons program run by the South African military, which operated from 1981 to 1992, according to reports in the South African press.

Eric Niiler, San Diego

One NIH official suggested that the committee wants to make sure that the guidelines are written in such a way that researchers do not have any questions about what is and is not allowed, and that it will take time to set up the final committee that will review stem cell research grant proposals. Researchers speculate that because of the political sensitivity of the issue, the NIH will stall release until after the federal appropriations process this fall, or even after the presidential elections.

Meanwhile, the delayed release of the guidelines has created an uneven playing field for NIH researchers compared with their privately funded counterparts, and has caused medical ethicists to worry that industry could pull so far ahead in this field of research that there may never be an opportunity for public oversight.

"It's dangerous that private companies are the only place where human pluripotent stem cell work is conducted," says Arlene Chiu, grants program director at the NINDS. "Companies focus on experiments of importance only to their needs. Because their funding base is much smaller than the NIH, they won't perform research on basic mechanisms or orphan diseases with small markets". She adds that industry will also decide what proportion of their research will be shared with the whole scientific community. "This is unlike NIH-funded research, where there is a peer review process to decide whether certain research is safe and ethical", says Chiu.

Kristine Novak, New York 